\title{
KEANEKARAGAMAN JENIS BURUNG PADA HUTAN DATARAN RENDAH DI KOMPLEKS GUNUNG BULUSARAUNG TAMAN NASIONAL BANTIMURUNG BULUSARAUNG
}

\author{
Bird Species Diversity in The Lowland Forests at the Complex of Bulusaraung Mountain, Bantimurung Bulusaraung \\ National Park
}

Risma Illa Maulany ${ }^{1}$, Jumriah Lira², Amran Achmad ${ }^{\otimes 1}$, Nida' Sari Achmad ${ }^{3}$

${ }_{1}^{1}$ Staf Pengajar, Fakultas Kehutanan, Universitas Hasanuddin, Makassar

2Mahasiswa, Laboratorium Konservasi Sumberdaya Hutan dan Ekowisata, Universitas Hasanuddin, Makassar

${ }^{3}$ Eco-Conservation Konsultan, Perdos Unhas Tamanalanrea Blok GB.45, Makassar

corresponding author: amhutan@yahoo.com

\begin{abstract}
Lowland Forest at the complex of Bulusaraung mountain in the Bantimurung Bulusaraung National Park is one of important habitat of birds in South Sulawesi. This study aimed to identify bird's diversity in the Lowland Forest of Bantimurung Bulusaraung National Park for ecotourism purposes. This research was carried out for 2 months between April and May 2018. The data were gathered by using line transect method. The data were analyzed by using Shannon-Weiner diversity index, Evenness index, Margalef species richness index, and Sorensen Similarity index. The result of the study showed that, there were 23 species of birds found in the three lines of observation tracks. There were 19 species found in Balleanging, 12 species in Kattokaddaro and 15 species found in Tompobulu. The highest value of bird diversity index was found in Tompobulu $\left(H^{\prime}=1,73\right)$ followed by Balleanging $\left(H^{\prime}=1,54\right)$ and Kattokaddaro routes $\left(H^{\prime}=1,43\right)$. Therefore, the diversity of bird species in the three observation pathways can be used as objects and attractions in the development of ecotourism based on bird watching in wildlife conservation efforts.
\end{abstract}

Keywords: Lowland Forest, Bulusaraung Mountant, Bantimurung Bulusaraung National Park, Bird diversity

\section{A. PENDAHULUAN}

Burung merupakan salah satu jenis aves vertebrata (bertulang belakang) dan masuk ke dalam phylum chordata (Welty, 1982). Menurut Hernowo dan Prasetyo (1989), burung termasuk satwa yang harus dilestarikan karena mempunyai manfaat sebagai sumber plasma nutfah, membantu mengendalikan hama, suaranya menyenangkan bagi manusia, sebagai objek pendididkan dan penelitian. Burung hantu adalah salah satu jenis burung yang mempunyai fungsi ekologi penting sebagai pengendali populasi tikus (Rattus argentiventer), karena $99 \%$ makanannya adalah tikus. Beberapa jenis burung lain seperti kuntul, ataupun perenjak yang hidup di sawah juga dapat mengatasi hama karena mereka memakannya dalam jumlah besar (MacKinnon, 1992).

Indonesia merupakan negara dengan potensi keanekaragaman jenis burung yang tinggi mencapai 1598 jenis burung dan 372 jenis diantaranya adalah endemik (Sukmantoro,dkk., 2007). Tingginya tingkat keanekaragaman jenis burung ini terkait dengan letak Indonesia yang meliputi wilayah zoogeografis antara kawasan Oriental dan Australia serta wilayah peralihan yaitu Wallacea (Ismawan, dkk., 2015). Wilayah Wallacea dikelompokkan menjadi tiga kelompok utama kepulauan yang disebut subkawasan: (1) subkawasan Sulawesi; (2) subkawasan Maluku; (3) subkawasan Nusa Tenggara. Sulawesi dan pulau-pulau kecil disekitarnya memiliki 96 jenis burung endemik dari 380 jenis burung (Holmes dan Phillips, 1999). Sulawesi Selatan merupakan salah satu wilayah di Indonesia yang masuk kedalam wilayah Wallacea. Sulawesi Selatan termasuk Wilayah Wallacea dengan tingkat keanekaragaman jenis burung yang cukup tinggi. Menurut Coates, dkk. (2000), Wilayah Wallacea memiliki 249 jenis burung endemik, hal inilah yang berperan penting dalam menempatkan Indonesia sebagai negara dengan tingkat endemisitas tertinggi di dunia.

Kawasan Taman Nasional Bantimurung Bulusaraung telah terdaftar sebanyak 356 species satwa liar. Jenisjenis satwa liar tersebut terdiri dari 6 species Mamalia, 73 species Aves, 7 species Amphibi, 19 species Reptilia, 224 species Insecta, serta 27 species Collembola, Pisces, Moluska dan lain sebagainya. Selain jenis-jenis satwa liar, terdapat juga 302 species tumbuhan alam telah terdaftar pada kawasan Taman Nasional Bantimurung Bulusaraung yang terdiri dari 2 family kelas Monocotyledonae dan 43 
family kelas Dicotyledonae. Suatu hal yang cukup unik dari keberadaan tumbuhan alam tersebut adalah adanya 40 species tumbuhan alam dari marga Ficus. Jenis-jenis Ficus ini adalah makanan utama bagi banyak jenis satwa liar termasuk pula yang paling umum Kera Hitam Sulawesi/ Dare (Macaca maura) (Departemen Kehutanan, 2010).

Keanekaragaman jenis burung yang melimpah sangat berpotensial untuk dikembangkan sebagai daya tarik wisata di Taman Nasional Bantimurung Bulusaraung, khususnya dalam kegiatan ekowisata. Ekowisata adalah perjalanan yang bertanggung jawab ke tempat-tempat yang alami dengan menjaga kelestarian lingkungan dan meningkatkan kesejahteraan penduduk setempat, memberikan dampak langsung terhadap konservasi kawasan, berperan dalam usaha-usaha pemberdayaan ekonomi masyarakat lokal, dan mendorong konservasi dan pembangunan berkelanjutan, dan bahkan menjadi alat kebijakan ekonomi di negara-negara berkembang (Yoeti, 2000). Ekowisata merupakan salah satu kegiatan pariwisata berwawasan lingkungan dengan mengutamakan aspek konservasi alam, aspek pemberdayaan sosial budaya ekonomi masyarakat lokal, serta aspek pembelajaran dan pendidikan, sehingga semua pihak ikut berperan dalam melestarikan sumberdaya alam serta menyusun strategi pelestarian keanekaragaman hayati agar kerusakan sumberdaya alam bisa dicegah.

Gunung Bulusaraung merupakan salah satu kawasan yang ada di Taman Nasional BantimurungBulusaraung yang saat ini sering didaki oleh para pemanjat gunung dan aktivis pencinta alam serta merupakan kawasan yang akan dikembangkan sebagai salah satu kawasan ekowisata. Gunung ini memiliki ketinggian 1300 di atas permukaan laut dan terdiri dari hutan dataran rendah dan hutan pegunungan bawah. Namun, tidak banyak studi satwa khususnya burung yang dilakukan di kawasan ini. Oleh karena burung memiliki potensi untuk dekembaangkan sebagai obyek wisata, maka perlu penelitian terkait keanekaragaman jenis burung di kompleks Gunung Bulusaraung, khususnya pada hutan dataran rendah pada wilayah Taman Nasional Bantimurung Bulusaraung. Penelitian ini akan membantu pihak pengelola taman nasional sebagai data dasar dalam pengembangan ekowisata di kawasan tersebut, yang dapat memberikan nilai positif bagi kawasan terkait upaya perlindungan kawasan itu sendiri, pendidikan lingkungan bagi masyarakat, serta peran positifnya terhadap pembangunan ekonomi masyarakat khususnya masyarakat di sekitar kawasan. Penelitian ini bertujuan untuk mengidentifikasi keanekaragaman burung di Hutan Dataran Rendah Taman Nasional Bantimurung Bulusaraung untuk tujuan pengembangan ekowisata

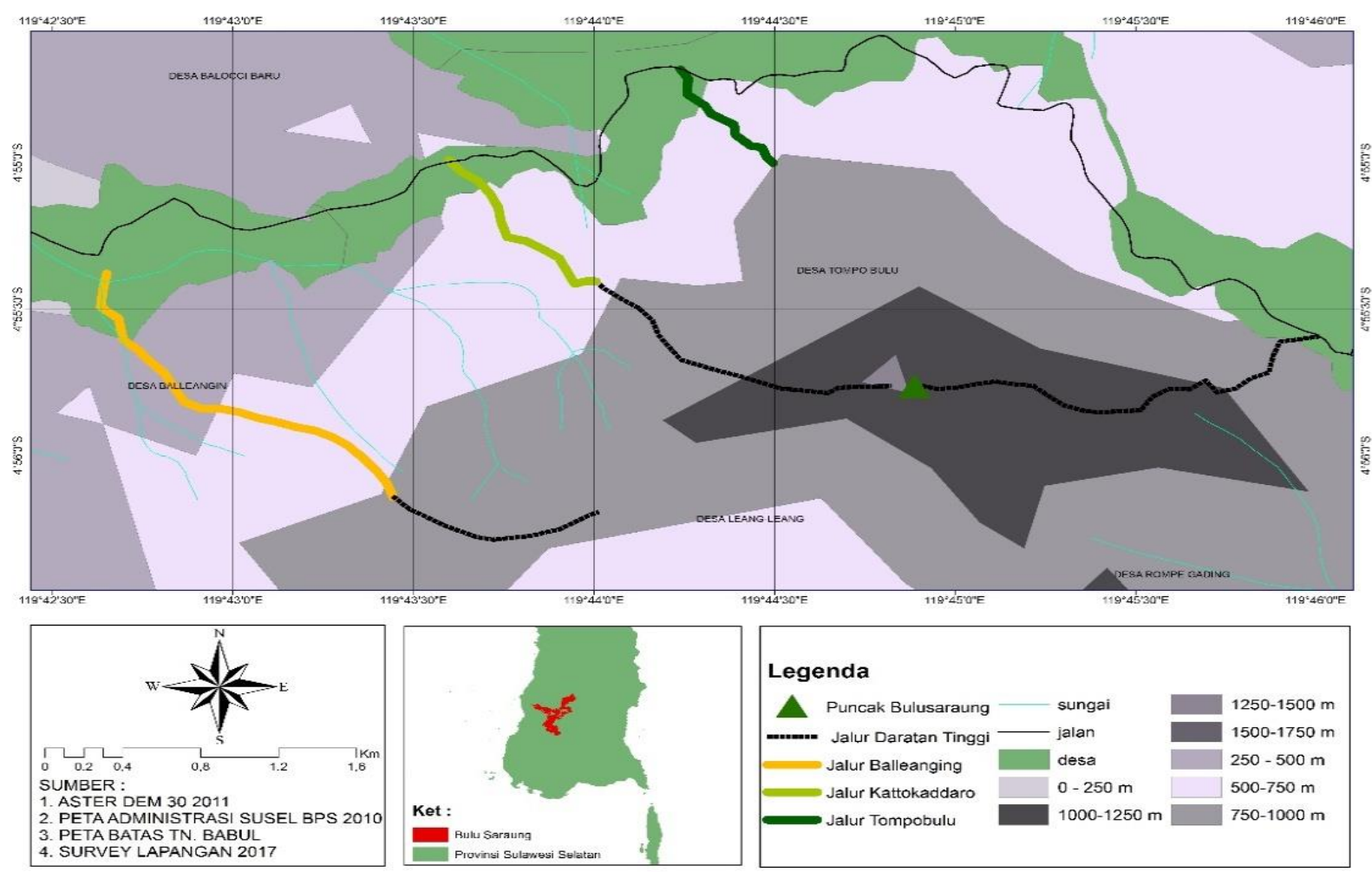

Gambar 1. Jalur Pengamatan Burung di Gunung Bulusaraung, Taman Nasional Bantimurung Bulusaraung 


\section{B. METODE}

Penelitian dilaksanakan selama 2 bulan, yaitu mulai bulan April hingga Maret 2018. Lokasi penelitian bertempat di Hutan Dataran Rendah Kompleks Gunung Bulusaraung Taman Nasional Bantimurung Bulusaraung. Adapun alat dan bahan yang digunakan dalam penelitian ini antara lain, Meteran roll, binokuler, kompas, kamera, receiver GPS, jam digital, buku panduan lapangan burungburung di kawasan Wallaceae oleh Brian J. Coates dan K. David Bishop, alat tulis menulis, dan tally sheet.

\section{Metode Pengumpulan Data}

\section{Metode Transek Garis (line transect)}

Metode garis transek ini dilakukan dengan berjalan sepanjang garis transek dan pengamatan dilakukan di kedua sisi transek, kemudian jarak antara lokasi burung yang terlihat dengan pengamat diukur panjangnya. Metode line transect ini diletakkan pada tiga jalur pengamatan yang mengarah ke puncak Gunung Bulusaraung, yakni jalur Balleanging, jalur Kattokaddaro dan jalur Tompobulu yang berupa jalan setapak yang dimulai pada ketinggian $150 \mathrm{mdpl}$ sampai ketinggian 750 mdpl. Sepanjang jalur pengamatan, pada setiap jarak 100 $\mathrm{m}$ dalam garis transek, akan diberi tanda sebagai sub jalur pengamatan. Inventarisasi burung dilakukan tiga kali dalam sehari, yakni pagi hari mulai pukul $6.00-11.00$ Wita, siang hari mulai pukul 13.00 - 15.00 Wita dan sore hari mulai pukul 16.00 - 18.00 Wita. Pengulangan pengumpulan data dilakukan sebanyak tiga kali pada setiap jalur pengamatan. Untuk lebih jelasnya ketiga jalur pengamatan dapat dilihat pada Gambar 1.

\section{Analisis Data}

Analisis kualitatif dilakukan untuk mendeskripsikan aktivitas burung, habitat dan perilaku burung yang dijumpai. Sedangkan analisis kuantitatif dilakukan untuk memperoleh data luas plot pengamatan, kepadatan, frekuensi, indeks keanekaragaman jenis, indeks kekayaan, indeks kemerataan, dan indeks kesamaan jenis burung.

\section{HASIL DAN PEMBAHASAN}

\section{Hasil}

\section{Deskripsi Lokasi Pengamatan}

\section{Jalur Balleanging}

Secara umum areal pengamatan di dominasi oleh areal perkebunan warga sekitar hutan dengan topografi yang bergelombang dan medan yang tidak terlalu terjal. Pada jalur pengamatan ini terdapat 21 plot pengamatan dengan panjang jalur 2.100 meter dengan ketinggian 150 mdpl sampai ketinggian $750 \mathrm{mdpl}$. Pada jalur Balleanging banyak terdapat areal terbuka untuk melakukan pengamatan burung, salah satunya burung elang yang melakukan soaringdikarenakan jalur tersebut didominasi oleh perkebunan atau ladang warga di sekitar hutan yang berada pada sub plot 1 sampai dengan sub plot 7 , sedangkan pada sub plot 8 sampai 21 areal pengamatan mulai di dominasi oleh vegetasi yang rapat. Pada jalur pengamatan ini terdapat 21 sub plot pengamatan dengan panjang jalur 2100 meter yang berada pada ketinggian $150 \mathrm{mdpl}$ sampai dengan $750 \mathrm{mdpl}$.

\section{Jalur Kattokaddaro}

Secara umum areal pengamatan di dominasi oleh areal perkebunan warga sekitar hutan dengan topografi yang bergelombang dan medan yang tidak terlalu terjal. Dibandingkan pada jalur Balleanging, sebagian areal pengamatan didominasi oleh semak belukar dan tutupan vegetasi di beberapa plot tertentu.Pada jalur Kattokaddaro terdapat 11 sub plot pengamatan dengan panjang jalur 1.100 meter dengan ketinggian $350 \mathrm{mdpl}$ sampai dengan ketinggian $750 \mathrm{mdpl}$. Pada jalur pengamatan terdapat beberapa sub plot pengamatan yang merupakan areal terbuka yang memungkinkan untuk dapat melihat Burung elangmelakukan soaring.

\section{Jalur Tompobulu}

Pada jalur Tompobulu plot awal dimulai dari seberang jalan poros antara Desa Balleanging ke Desa Tompobulu. Secara umum areal pengamatan bervegatasi rapat.Topografi areal lebih tinggi dibandingkan pada jalur Balleanging dan jalur Kattokaddaro. Pada jalur Tompobulu terdapat 4 plot pengamatan dengan panjang jalur 400 meter dengan ketinggian $550 \mathrm{mdpl}$ sampai dengan ketinggian 750 mdpl. Pada jalur pengamatan terdapat sub plot pengamatan yang merupakan areal terbuka pada areal jalan poros yang memungkinkan untuk dapat melihat burung elang melakukan soaring.

\section{Jenis Burung}

Berdasarkan dari hasil pengamatan yang dilakukan dengan menggunakan metode line transect untuk ketiga jalur pengamatan ditemukan berbagai jenis burung. Jumlah keseluruhan jenis burung yang dijumpai pada jalur pengamatan dapat dilihat pada Tabel 1 .

Berdasarkan Tabel 1, diketahui bahwa ada 23 jenis burung yang ditemukan di lokasi penelitian. Jumlah jenis burung yang dijumpai pada jalur Balleanging sebanyak 19 jenis dengan jumlah individu 669. Pada jalur Kattokaddaro dijumpai sebanyak 12 jenis dengan jumlah individu

341. Sedangkan pada jalur Tompobulu dijumpai sebanyak 15 jenis dan jumlah individu 234. Dari keseluruhan jenis burung tersebut ada yang dijumpai hanya pada satu jalur pengamatan atau tempat tertentu, ada yang dijumpai di dua jalur pengamatan dan beberapa dijumpai di setiap jalur pengamatan. 


\section{Kepadatan Jenis Burung}

\section{Jalur Balleanging}

Hasil perhitungan kepadatan jenis burung berdasarkan pengamatan diperlihatkan pada Tabel 2. Dari tabel tersebut diketahui bahwa keseluruhan jenis burung yang ditemukan pada jalur pengamatan didapatkansatu jenis burung yang mempunyai kepadatan tinggi pada pengamatan pagi, siang dan sore hari, yaitu Layanglayang batu (Hirundo tahitica) dengan kepadatan 41 individu/luas plot pada pengamatan pagi, 43 individu/luas plot pada pengamatan siang dan 57 individu/luas plot pada pengamatan sore.

\section{Jalur Kattokaddaro}

Hasil perhitungan kepadatan jenis burung berdasarkan pengamatan diperlihatkan pada Tabel 3 . Berdasarkan Tabel 3 menunjukkan bahwa dari keseluruhan jenis burung yang ditemukan satu jenis burung yang mempunyai kepadatan tinggi pada pengamatan pagi, siang dan sore hari, yaitu Layanglayang batu (Hirundo tahitica) dengan kepadatan 17 individu/luas plot pada pengamatan pagi, 19 individu/luas plot pada pengamatan siang dan 28 individu/luas plot pada pengamatan sore.

\section{Jalur Tompobulu}

Hasil perhitungan kepadatan jenis burung dapat dilihat pada Tabel 4. Tabel ini memperlihatkan bahwa dari keseluruhan jenis burung yang ditemukan satu jenis burung yang mempunyai kepadatan tinggi pada pengamatan pagi, siang dan sore hari, yaitu Layanglayang batu (Hirundo tahitica) dengan kepadatan 43 individu/luas plot pada pengamatan pagi, 21 individu/luas plot pada pengamatan siang dan 29 individu/luas plot pada pengamatan sore.

Tabel 1. Jumlah burung yang ditemukan selama 3 hari pengamatan di hutan pegunungan bawah gunung Bulusaraung, Taman Nasional Bantimutung Bulusaraung, Kabupaten Pangkep, Sulawesi Selatan

\begin{tabular}{|c|c|c|c|c|c|c|}
\hline \multirow[t]{2}{*}{ No } & \multirow[t]{2}{*}{ Nama latin } & \multirow[t]{2}{*}{ Nama lokal } & \multirow[t]{2}{*}{ Family } & \multicolumn{3}{|c|}{$\begin{array}{l}\text { Jumlah Individu per } \\
\text { jalur }\end{array}$} \\
\hline & & & & $B$ & K & $\mathrm{T}$ \\
\hline 1 & Hirundo rustica & Layang-layang api & Hirundinidae & 8 & 15 & 39 \\
\hline 2 & Hirundo tahitica & Layang-layang batu & Hirundinidae & 424 & 205 & 111 \\
\hline 3 & Collocalia esculenta & Walet sapi & Apodidae & 59 & - & - \\
\hline 4 & Collocalia vanikorensis & Walet polos & Apodidae & 12 & 38 & 31 \\
\hline 5 & Dicaeum aureolimbatum & Cabai panggul-kuning* & Dicaeidae & 22 & 8 & - \\
\hline 6 & Dicaeum monticulum & Cabai panggul hitam & Dicaeidae & 26 & - & - \\
\hline 7 & Pycnonotus aurigaster & Cucak kutilang & Pycnonotidae & 38 & 38 & 16 \\
\hline 8 & Nectarinia Aspasia & Burung madu hitam\# & Nectariniidae & 2 & - & 1 \\
\hline 9 & Nectarinia jugularis & Burung madu sriganti\# & Nectariniidae & 1 & - & - \\
\hline 10 & Zosterops consobrinorum & Kacamata sulawesi* & Zosteropidae & - & - & 1 \\
\hline 11 & Phaenicophaeus calyorhynchus & Kadalan sulawesi* & Cuculidae & 2 & - & 6 \\
\hline 12 & Clamator coromandus & Bubut pacar jambul & Cuculidae & 8 & - & - \\
\hline 13 & Rhyticeros cassidix & Julang sulawesi# & Bucerotidae & 5 & 4 & 4 \\
\hline 14 & Penelopides exarthatus & Kangkareng sulawesi*\# & Bucerotidae & - & - & - \\
\hline 15 & Falco molusccensis & Alap-alap sapi\# & Falconidae & 2 & 5 & 3 \\
\hline 16 & Accipiter nanus & Elang alap kecil# & Accipitridae & 3 & 5 & 1 \\
\hline 17 & Ictinaetus malayensis & Elang hitam\# & Accipitridae & - & 3 & 3 \\
\hline 18 & Dicaeum celebicum & Cabai panggul kelabu* & Dicaeidae & 18 & - & 2 \\
\hline 19 & Spilornis rifipectus & Elang ular sulawesi# & Accipitridae & 1 & - & 4 \\
\hline 20 & Centropus bengalensis & Bubut sulawesi* & Cuculidae & - & 2 & 1 \\
\hline 21 & Dicrurus montanus & Srigunting sulawesi* & Dicruridae & 16 & 17 & 11 \\
\hline 22 & Ninox scutulata & Punggok coklat & Strigidae & 8 & 1 & - \\
\hline 23 & Saxicola caprata & Decu belang & Muscicapidae & 14 & - & - \\
\hline & TOTAL & & & 669 & 341 & 234 \\
\hline
\end{tabular}

Keterangan: * Endemik sulawesi , \# Dilindungi 
Tabel 2. Kerapatan burung pada jalur Balleanging di Hutan Pengunungan Bawah gunung Bulusaraung, Taman Nasional Bantimurung Bulusaraung, Kabupaten Pangkep, Sulawesi Selatan

\begin{tabular}{lllccc}
\hline \multirow{2}{*}{ No } & \multicolumn{1}{c}{ Nama Latin } & \multicolumn{1}{c}{ Nama Lokal } & \multicolumn{2}{c}{$\begin{array}{c}\text { Kepadatan Rata-Rata Jenis } \\
\text { (individu/luas plot) }\end{array}$} \\
\cline { 4 - 6 } & & Pagi & Siang & Sore \\
\hline 1 & Hirundo rustica & Layang-layang api & 0 & 1 & 1 \\
2 & Hirundo tahitica & Wang-layang batu & 41 & 43 & 57 \\
3 & Collocalia esculenta & Walet polos & 9 & 3 & 7 \\
4 & Collocalia vanikorensis & Cabai panggul-kuning* & 1 & 1 & 2 \\
5 & Dicaeum aureolimbatum & Cabai panggul hitam & 3 & 3 & 2 \\
6 & Dicaeum monticulum & Cucak kutilang & 4 & 2 & 2 \\
7 & Pycnonotus aurigaster & Burung madu hitam\# & 3 & 6 & 4 \\
8 & Nectarinia Aspasia & Burung madu sriganti & 0 & 1 & 0 \\
9 & Nectarinia jugularis & Kadalan sulawesi* & 0 & 0 & 0 \\
10 & Phaenicophaeus calyorhynchus & Bubut pacar jambul & 0 & 0 & 0 \\
11 & Clamator coromandus & Julang sulawesi*\# & 0 & 2 & 1 \\
12 & Rhyticeros cassidix & Kangkareng sulawesi*\# & 1 & 0 & 0 \\
13 & Penelopides exarthatus & Alap-alap sapi\# & 0 & 1 & 0 \\
14 & Falco molusccensis & Elang hitam\# & 0 & 1 & 0 \\
15 & Ictinaetus malayensis & Elang ular sulawesi*\# & 3 & 1 & 3 \\
16 & Spilornis rifipectus & Srigunting sulawesi* & 0 & 0 & 0 \\
17 & Dicrurus montanus & Punggok coklat & 2 & 2 & 1 \\
18 & Ninox scutulata & Decu belang & 1 & 1 & 1 \\
19 & Saxicola caprata & & 2 & 1 & 2 \\
\hline
\end{tabular}

Keterangan: * Endemik Sulawesi, \# Dilindungi

Tabel 3. Kerapatan burung pada jalur Kattokaddaro di hutan pengunungan bawah gunung Bulusaraung, Taman Nasional Bantimurung Bulusaraung, Kabupaten Pangkep, Sulawesi Selatan

\begin{tabular}{|c|c|c|c|c|c|}
\hline \multirow[t]{2}{*}{ No. } & \multirow[t]{2}{*}{ Nama Latin } & \multirow[t]{2}{*}{ Nama Lokal } & \multicolumn{3}{|c|}{$\begin{array}{c}\text { Rata-rata Kepadatan } \\
\text { (individu/luas plot) }\end{array}$} \\
\hline & & & Pagi & Siang & Sore \\
\hline 1 & Hirundo rustica & Layang-layang api & 1 & 2 & 1 \\
\hline 2 & Hirundo tahitica & Layang-layang batu & 17 & 19 & 28 \\
\hline 3 & Collocalia vanikorensis & Walet polos & 3 & 1 & 7 \\
\hline 4 & Dicaeum aureolimbatum & Cabai panggul-kuning* & 2 & 0 & 1 \\
\hline 5 & Pycnonotus aurigaster & Cucak kutilang & 3 & 6 & 3 \\
\hline 6 & Centropus bengalensis & Bubut sulawesi ${ }^{*}$ & 1 & 0 & 0 \\
\hline 7 & Rhyticeros cassidix & Julang sulawesi# & 0 & 1 & 1 \\
\hline 8 & Falco molusccensis & Alap-alap sapi\# & 1 & 1 & 0 \\
\hline 9 & Accipiter nanus & Elang alap kecil#\# & 1 & 1 & 0 \\
\hline 10 & Ictinaetus malayensis & Elang hitam\# & 0 & 0 & 0 \\
\hline 11 & Dicrurus montanus & Srigunting sulawesi* & 2 & 1 & 2 \\
\hline 12 & Ninox scutulata & Punggok coklat & 0 & 0 & 0 \\
\hline
\end{tabular}

Keterangan: * Endemik Sulawesi, \# Dilindungi

\section{Frekuensi Kemunculan Jenis Burung}

\section{Jalur Balleanging}

Hasil perhitungan frekuensi kemunculan jenis burung di lokasi penelitian diperlihatkan pada Tabel 5 . Berdasarkan Tabel 5 menunjukkan bahwa Layang-layang batu (Hirundo tahitica) mempunyai frekuensi kehadiran tinggi pada waktu pengamatan pagi, siang soredengan frekuensi kehadiran sebesar $57,14 \%$ pada pengamatan pagi, $63,68 \%$ pada pengamatan siang dan $68,53 \%$ pada pengamatan sore. Adapun jenis burung Kadalan Sulawesi (Phaenicophaeus calyorhynchus) yang hanya muncul apabila terdapat kelompok Monyet Sulawesi (Macaca Maura). 
Tabel 4. Kerapatan burung jalur Tompobulu di hutan pegunungan bawah gunung Bulusaraung, Taman Nasional Bantimurung Bulusaraung, Kabupaten Pangkep, Sulawesi Selatan

\begin{tabular}{|c|c|c|c|c|c|}
\hline \multirow[t]{2}{*}{ No. } & \multirow[t]{2}{*}{ Nama Latin } & \multirow[t]{2}{*}{ Nama Lokal } & \multicolumn{3}{|c|}{$\begin{array}{c}\text { Rata-rata Kepadatan } \\
\text { (individu/luas plot) }\end{array}$} \\
\hline & & & Pagi & Siang & Sore \\
\hline 1 & Hirundo rustica & Layang-layang api & 13 & 12 & 8 \\
\hline 2 & Hirundo tahitica & Layang-layang batu & 43 & 21 & 29 \\
\hline 3 & Collocalia vanikorensis & Walet polos & 9 & 8 & 10 \\
\hline 4 & Dicaeum celebicum & Cabai panggul kelabu* & 1 & 0 & 0 \\
\hline 5 & Pycnonotus aurigaster & Cucak kutilang & 0 & 11 & 4 \\
\hline 6 & Nectarinia Aspasia & Burung madu hitam\# & 1 & 0 & 0 \\
\hline 7 & Zosterops consobrinorum & Kacamata sulawesi* & 1 & 0 & 0 \\
\hline 8 & Phaenicophaeus calyorhynchus & Kadalan sulawesi ${ }^{*}$ & 3 & 2 & 0 \\
\hline 9 & Centropus bengalensis & Bubut sulawesi* & 0 & 0 & 1 \\
\hline 10 & Rhyticeros cassidix & Julang sulawesi*\# & 1 & 1 & 2 \\
\hline 11 & Falco molusccensis & Alap-alap sapi\# & 2 & 1 & 0 \\
\hline 12 & Accipiter nanus & Elang alap kecil# & 0 & 1 & 0 \\
\hline 13 & Ictinaetus malayensis & Elang hitam\# & 1 & 0 & 2 \\
\hline 14 & Spilornis rifipectus & Elang ular sulawesi# & 1 & 1 & 1 \\
\hline 15 & Dicrurus montanus & Srigunting sulawesi* & 3 & 5 & 3 \\
\hline
\end{tabular}

Keterangan: * Endemik Sulawesi, \# Dilindungi

Tabel 5. Frekuensi burung pada jalur Balleanging di hutan pengunungan bawah gunung Bulusaraung, Taman Nasional Bantimurung Bulusaraung, Kabupaten Pangkep, Sulawesi Selatan

\begin{tabular}{|c|c|c|c|c|c|}
\hline \multirow{2}{*}{ No. } & \multirow{2}{*}{ Nama Latin } & \multirow{2}{*}{ Nama Lokal } & \multicolumn{3}{|c|}{ Frekuensi relatif (\%) } \\
\hline & & & Pagi & Siang & Sore \\
\hline 1 & Hirundo rustica & Layang-layang api & 0,46 & 1,99 & 1,20 \\
\hline 2 & Hirundo tahitica & Layang-layang batu & 57,14 & 63,68 & 68,53 \\
\hline 3 & Collocalia esculenta & Walet sapi & 12,44 & 4,98 & 8,76 \\
\hline 4 & Collocalia vanikorensis & Walet polos & 0,92 & 1,49 & 2,79 \\
\hline 5 & Dicaeum aureolimbatum & Cabai panggul-kuning* & 3,69 & 3,98 & 2,39 \\
\hline 6 & Dicaeum monticulum & Cabai panggul hitam & 5,99 & 2,99 & 2,79 \\
\hline 7 & Pycnonotus aurigaster & Cucak kutilang & 4,61 & 8,46 & 4,38 \\
\hline 8 & Nectarinia Aspasia & Burung madu hitam\# & 0 & 1 & 0 \\
\hline 9 & Nectarinia jugularis & Burung madu sriganti & 0,46 & 0 & 0 \\
\hline 10 & Phaenicophaeus calyorhynchus & Kadalan sulawesi* & 0,46 & 2,49 & 1 \\
\hline 11 & Clamator coromandus & Bubut pacar jambul & 1,84 & 0 & 0,40 \\
\hline 12 & Rhyticeros cassidix & Julang sulawesi*\# & 0 & 1 & 0 \\
\hline 13 & Penelopides exarthatus & Kangkareng sulawesi# & 0,46 & 1 & 0 \\
\hline 14 & Falco molusccensis & Alap-alap sapi\# & 3,69 & 1 & 3,19 \\
\hline 15 & Ictinaetus malayensis & Elang hitam\# & 0,46 & 0 & 0 \\
\hline 16 & Spilornis rifipectus & Elang ular sulawesi*\# & 3,23 & 2,99 & 1,20 \\
\hline 17 & Dicrurus montanus & Srigunting sulawesi* & 0,92 & 1,49 & 1,20 \\
\hline 18 & Ninox scutulata & Punggok coklat & 2,76 & 1,00 & 2,39 \\
\hline 19 & Saxicola caprata & Decu belang & 0,46 & 1,99 & 1,20 \\
\hline
\end{tabular}

Keterangan: * Endemik Sulawesi, \# Dilindungi 
Tabel 6. Frekuensi burung pada jalur Kattokaddoro di hutan pengunungan bawah gunung Bulusaraung, Taman Nasional Bantimurung Bulusaraung, Kabupaten Pangkep, Sulawesi Selatan

\begin{tabular}{cllccc}
\hline \multirow{2}{*}{ No. Nama Latin } & & \multicolumn{2}{c}{ Nama Lokal } & \multicolumn{3}{c}{ Frekuensi relatif (\%) } \\
\cline { 4 - 6 } & & & Pagi & Siang & Sore \\
\hline 1 & Hirundo rustica & Layang-layang api & 4,26 & 7,62 & 2,11 \\
2 & Hirundo tahitica & Layang-layang batu & 54,26 & 60,95 & 63,38 \\
3 & Collocalia vanikorensis & Walet polos & 10,64 & 3,81 & 16,90 \\
4 & Dicaeum aureolimbatum & Cabai panggul-kuning* & 5,32 & 1 & 1,41 \\
5 & Pycnonotus aurigaster & Cucak kutilang & 10,64 & 18,10 & 6,34 \\
6 & Centropus bengalensis & Bubut sulawesi* & 2,13 & 0 & 0 \\
7 & Rhyticeros cassidix & Julang sulawesi*\# & 0 & 1,90 & 1,41 \\
8 & Falco molusccensis & Alap-alap sapi\# & 2,13 & 1,90 & 1 \\
9 & Accipiter nanus & Elang alap kecil* & 2,13 & 1,90 & 1 \\
10 & Ictinaetus malayensis & Elang hitam\# & 1,06 & 1 & 1 \\
11 & Dicrurus montanus & Srigunting sulawesi* & 7,45 & 1,90 & 5,63 \\
12 & Ninox scutulata & Punggok coklat & 0 & 0 & 3,03 \\
\hline
\end{tabular}

Keterangan: * Endemik Sulawesi, \# Dilindungi

Table 7. Frekuensi burung pada jalur Tompobulu di hutan pengunungan bawah gunung Bulusaraung, Taman Nasional Bantimurung Bulusaraung, Kabupaten Pangkep, Sulawesi Selatan

\begin{tabular}{lllccc}
\hline \multirow{2}{*}{ No } & \multirow{2}{*}{ Nama Latin } & \multicolumn{2}{c}{ Nama Lokal } & \multicolumn{3}{c}{ Frekuensi relatif (\%) } \\
\cline { 4 - 6 } & & Layang-layang api & 17,31 & 18,75 & 13,64 \\
\hline 1 & Hirundo rustica & Layang-layang batu & 54,81 & 34,38 & 48,48 \\
2 & Hirundo tahitica & Walet polos & 11,54 & 12,50 & 16,67 \\
3 & Collocalia vanikorensis & Cabai panggul kelabu* & 1,92 & 0 & 0 \\
4 & Dicaeum celebicum & Cucak kutilang & 0 & 17,19 & 7,58 \\
5 & Pycnonotus aurigaster & Burung madu hitam\# & 1 & 0 & 0 \\
6 & Nectarinia Aspasia & Kacamata sulawesi* & 1 & 0 & 0 \\
7 & Zosterops consobrinorum & Kadalan sulawesi* & 3,85 & 3,13 & 0 \\
8 & Phaenicophaeus calyorhynchus & 0 & 0 & 1,52 \\
9 & Centropus bengalensis & Bubut sulawesi* & 1 & 1,56 & 3,03 \\
10 & Rhyticeros cassidix & Julang sulawesi*\# & 1,92 & 1,56 & 0 \\
11 & Falco molusccensis & Alap-alap sapi\# & 0 & 1,56 & 0 \\
12 & Accipiter nanus & Elang alap kecil \# & 1 & 0 & 3,03 \\
13 & Ictinaetus malayensis & Elang hitam\# & 1,92 & 1,56 & 1,52 \\
14 & Spilornis rifipectus & Elang ular sulawesi*\# & 2,88 & 7,81 & 4,55 \\
15 & Dicrurus montanus & Srigunting sulawesi* & & & 0 \\
\hline
\end{tabular}

\section{Jalur Kattokaddaro}

Hasil perhitungan frekuensi kemunculan jenis burung di lokasi penelitian diperlihatkan pada Tabel 6. Dari tabel tersebut terlihat bahwa Layang-layang batu (Hirundo tahitica) mempunyai frekuensi kehadiran tinggi pada waktu pengamatan pagi, siang sore dengan frekuensi kehadiran sebesar $54,26 \%$ pada pengamatan pagi, $60,95 \%$ pada pengamatan siang dan $63,38 \%$ pada pengamatan sore.

\section{Jalur Tompobulu}

Hasil perhitungan frekuensi kemunculan jenis burung di lokasi penelitian diperlihatkan pada Tabel 7. Dari tabel tersebut terlihat bahwa Layang-layang batu (Hirundo tahitica) mempunyai frekuensi kehadiran tinggi pada waktu pengamatan pagi, siang sore dengan frekuensi kehadiran sebesar $54,81 \%$ pada pengamatan pagi, $34,38 \%$ pada pengamatan siang dan $48,48 \%$ pada pengamatan sore. 


\section{Indeks Ekologi Jenis Burung}

Perhitungan indeks ekologis ini bertujuan untuk mengetauhi kestabilan komunitas jenis burung. Pada penelitian ini digunakan tiga indeks, yaitu indeks keanekaragaman jenis Shannon-Wiener untuk menunjukkan keanekaragaman jenis burung di areal pengamatan, indeks kekayaan jenis Margalef untuk menunjukkan kekayaan jenis burung di areal pengamatan, serta indeks kemerataan Shannon-Wiener untuk menunjukkan kemerataan jenis burung di areal pengamatan. Untuk analisis indeks ekologis, digunakan data dari hasil pengamatan metode line transect. Berikut indeks ekologi jenis burung pada jalur pengamatan Tompobulu diperlihatkan pada Tabel 8.

Tabel 8. Indeks ekologi pada 3 jalur pengamatan di hutan pengunungan bawah gunung Bulusaraung, Taman Nasional Bantimutung Bulusaraung, Kabupaten Pangkep, Sulawesi Selatan

\begin{tabular}{clccc}
\hline No. & Jalur pengamatan & Dmg & H' & E \\
\hline 1 & Jalur Balleanging & 2,77 & 1,54 & 0,52 \\
2 & Jalur Kattokaddaro & 1,89 & 1,43 & 0,58 \\
3 & Jalur Tompobulu & 2,57 & 1,73 & 0,64 \\
\hline
\end{tabular}

Tabel 8 di atas menunjukkan terdapat perbedaan nilai indeks ekologi yang diperoleh dari setiap jalur. Jalur Balleanging memiliki nilai indeks kekayaan 2,77, indeks keanekaragaman 1,54 dan indeks kemerataan 0,52 . Jalur kattokaddaro dengan nilai indeks kekayaan 1,89 , nilai indeks keanekaragaman 1,43 dan indeks kemerataan 0,58 . Jalur Tompobulu memiliki indeks kekayaan 2,57, indeks keanekaragaman 1,73 dan indeks kemerataan 0,64 . Nilai indeks keanekaragaman jenis burung tergolong rendah dan indeks kekayaan jenis burung tergolong rendah. Hal ini mengindikasikan bahwa ketiga jalur pengamatan tergolong rendah sebagai potensi pengembangan ekowisata satwa liar berbasis bird watching.

\section{Indeks Kesamaan Jenis Burung}

Perbedaan struktur dan komposisi habitat juga dapat dilihat melalui komposisi burung yang mendiami habitat tersebut. Kesamaan komposisi burung antar areal yang berbeda dapat mengindikasikan areal tersebut memiliki kesamaan struktur dan komposisi yang hampir serupa. Menurut Odum (1993), indeks kesamaan ini akan memiliki nilai sama dengan satu, apabila terdapat kesamaan secara penuh atau jika serangkaian spesies dari kedua komunitas yang dibandingkan identik. Nilai indeks kesamaan jenis burung pada ketiga jalur pengamatan berkisar $64 \%-74 \%$. Indeks kesamaan jenis burung pada ketiga jalur pengamatan dapat dilihat pada Tabel 9 .
Tabel 9. Indeks kesamaan jenis burung pada tiga jalur pengamatan di hutan pegunungan bawah gunung Bulusaraung, Taman Nasional Bantimurung Bulusaraung, Kabupaten Pangkep, Sulawesi Selatan

\begin{tabular}{cccccc}
\hline \multirow{2}{*}{ No } & \multirow{2}{*}{ Jalur } & $\begin{array}{c}\text { Jumlah } \\
\text { Jenis }\end{array}$ & & \multicolumn{3}{c}{$\begin{array}{c}\text { Indeks Kesamaan } \\
\text { Jenis (\%) }\end{array}$} \\
\cline { 4 - 6 } & & & $\mathbf{B}$ & $\mathbf{K}$ & $\mathbf{T}$ \\
\hline 1 & Balleanging & 19 & - & $64 \%$ & $70 \%$ \\
2 & Kattokaddaro & 12 & $64 \%$ & - & $74 \%$ \\
3 & Tompobulu & 15 & $70 \%$ & $74 \%$ & - \\
\hline
\end{tabular}

\section{Pembahasan}

Kawasan hutan dataran rendah pada ketiga jalur pengamatan di Kompleks Gunung Bulusaraung, Taman Nasional Bantimurung Bulusaraung didominasi oleh perkebunan dan semak belukar. Disetiap ketinggian tertentu terdapat tutupan vegetasi yang padat, dengan strata yang lengkap. Hutan dataran rendah di Kompleks Gunung Bulusaraung merupakan kawasan yang sering dilalui oleh masyarakat setempat untuk membawa hewan ternak seperti sapi dan hewan peliharaan seperti anjing untuk makan, juga dimanfaatkan sebagai areal perkebunan disekitar luar wilayah hutan. Lokasi hutan dataran rendah di Kompleks Gunung Bulusaraung memiliki areal jelajah yang tidak terlalu terjal sehingga tidak terlalu sulit untuk dijangkau.

Secara umum areal pengamatan bervegetasi rapat, didominasi oleh berbagai jenis tumbuhan seperti Tampalang kacci, Lento-lento(Arthopyllum), Tera-terasa (Dyctyoneura acuminate), dan Bintao(Calolphylum). Adapun areal pengamatan yang ditumbuhi oleh semak belukar dan areal perkebunan. Areal semak belukar dan perkebunan berfungsi sebagai tempat bertengger dan makan bagi beberapa jenis burung kecil yang areal jelajahnya tidak terlalu jauh. Hutan dataran rendah di Kompleks Gunung Bulusaraung mempunyai banyak areal terbuka yang memudahkan pengamatan burung yang melakukan soaring (terbang melayang).

Hasil penelitian memperlihatkan bahwa ekosistem hutan dataran rendah Kompleks Gunung Bulusaraung, Taman Nasional Bantimurung Bulusaraung tergolong memiliki keanekaragaman jenis yang rendah. Keanekaragaman jenis burung tertinggi terdapat pada jalur Balleanging yaitu 1,54. Hal ini dikarenakan jumlah jenis yang ditemukan sebanyak 19 jenis burung diantaranya terdapat 6 jenis burung endemik, 6 jenis burung dilindungi, dan 3 jenis burung endemik sekaligus dilindungi dengan panjang jalur 2100 meter. Berdasrkan hasil penelitian, faktor utama yang mempengaruhi tingginya keanekaragaman jenis pada jalur balleanging disebabkan oleh panjangnya jalur pengamatan. Adapun kondisi cuaca pada saat pengamatan terjadi hujan di waktu pagi (06.00-08.00) dan sore (16.00-17.00) selama 2 hari pengamatan. Faktor lain yang mempengaruhi seperti tipe habitat, struktur vegetasi, dan ketersediaan pangan. 
Sebagaiman yang dijelaskan oleh Tortosn dan Villafuerte (2000), keanekaragaman jenis burung dipengaruhi oleh keanekaragaman tipe habitat. Semakin beranekaragam struktur habitat (keanekaragaman jenis tumbuhan dan struktur vegetasi) maka akan semakin besar keanekaragaman jenis burung, karena ketersediaan pakan pada habitat seperti itu akan bervariasi. Keanekaragaman jenis burung yang diperoleh di jalur Balleanging lebih tinggi dibandingkan dengan keanekaragaman jenis burung pada jalur Tompobulu dan Jalur kattokaddaro. Faktor tingginya keanekaragaman pada jalur Balleanging disebabkan oleh banyaknya sumber pakan berupa serangga-serangga kecil, buahbuahan dan tingginya keanekaragaman habitat seperti vegetasi yang rapat, daerah sungai, dan semak belukar. Menurut Mendidit (2003), penyebaran burung erat hubugannya dengan kesediaan makanan, dengan kata lain burung memerlukan tempat khusus untuk hidupnya, penyebaran burung dipengaruhi oleh kesesuaian lingkungan hidup burung, meliputi adaptasi terhadap lingkungan, kompetisi dan seleksi alam.

Jalur Kattokaddaro merupakan jalur yang memiliki keanekaragaman jenis paling rendah dibandingkan dengan jalur lainnya. Hal tersebut dikarenakan kondisi areal pada jalur Kattokaddaro lebih di dominasi oleh bebatuan lepas dan Karst serta bervegetasi rapat dan beberapa lokasi yang di tumbuhi oleh semak belukar. Indeks keanekaragaman jenis burung pada jalur Kattokaddaro yaitu 1,43 dengan jumlah jenis yang ditemukan sebanyak 12 jenis burung, diantaranya terdapat 5 jenis burung endemik, 4 jenis burung dilindungi, dan 2 jenis burung endemik sekaligus dilindungi dengan panjang jalur 1100 meter. Menurut Partasasmita (2003), keanekaragaman jenis burung cenderung rendah dalam ekosistem yang terkendali secara fisik dan cenderung tinggi dalam ekosistem yang diatur secara biologi, ini terlihat dari keanekaragaman jenis burung yang ada pada hutan dataran rendah lebih rendah daripada keanekaragaman jenis burung yang ada pada hutan pegunungan bawah.

Jalur Tompobulu merupakan jalur yang terpendek itu dikarenakan $T_{0}$ dimulai pada ketinggian 550 dengan areal jelajah yang cukup terjal serta bervegetasi rapat, kondusi cuaca pada saat pengamatan terjadi hujan pada waktu pengamatan pagi antara jam 06.00-08.00. Indeks keanekaragaman jenis burung pada jalur Tompobulu yaitu 1,73 dengan jumlah jenis yang ditemukan sebanyak 15 jenis burung, diantaranya terdapat 8 jenis burung endemik, 6 jenis burung dilindungi, dan 3 jenis burung endemik sekaligus dilindungi dengan panjang jalur 400 meter. Menurut Mendidit (2003), habitat merupakan hal utama yang dapat mempengaruhi kelimpahan burung serta ukuran atau luas habitat merupakan suatu faktor penting dalam menilai keanekaragaman burung. Struktur vegetasi dan ketersediaan pakan pada habitat merupakan faktor utama yang mempengaruhi keanekaragaman jenis di suatu tempat. Menurut Krebs dan Davides (1978), ketidakhadiran suatu jenis burung di suatu tempat disebabkan oleh beberapa faktor diantaranya ketidakcocokan habitat, perilaku (seleksi habitat), kehadiran jenis hewan lain (predator, pesaing, dan parasit), dan faktor kimia fisika lingkungan yang berada di luar kisaran toleransi jenis burung yang bersangkutan. Achmad (2017), menyatakan bahwa pentingnya penilaian indeks ekologi dalam mengkaji objek ekowisata sebagai data dasar dalam pengembangan ekowisata dan bahan interpretasi untuk memberikan informasi ilmiah kepada wisatawan. Selain itu melalui data tersebut dapat digunakan untuk mengukur dampak dari perubahan ekosistem baik dampak positif maupun negative dengan melihat perubahan yang terjadi untuk dapat dilakukan tindakan pengelolaan lebih lanjut.

Dari ketiga jalur pengamtan, terdapat 10 jenis burung endemik dan 8 jenis burung yang dilindungi serta 4 jenis burung endemic sekaligus dilindungi. Hal tersebut menandakan bahwa kawasan hutan dataran rendah di kompleks Gunung Bulusaraung, Taman Nasional Bantimurung Bulusaraung mampu mendukung kehidupan baik jenis endemik secara umum maupun jenis-jenis yang terancam punah. Berdasarkan PP No. 7 Tahun 1999 jenis burung yang dilindungi antara lain Burung madu sriganti (Nectarinia jugularis), Burung madu hitam (Nectarinia Aspasia). Selain dilindungi oleh pemerintah lokal juga digolongkan dalam Appendix II oleh CITES adalah Elang alap kecil (Accipiter nanus), Alap-alap sapi (Falco molusccensis), Elang hitam (Ictinaetus malayensis), Julang sulawesi (Rhyticeros cassidix), Kangkareng sulawesi (Penelopides exarthatus), dan Elang ular sulawesi (Spilornis rufipectus).

Terdapat beberapa aktivitas yang dilakukan oleh burung yang ditemukan selama penelitian antara lain makan, bertengger (vokal atau bersuara) dan bergerak atau terbang. Aktivitas-aktivitas tersebut merupakan aktivitas yang umum dilakukan oleh jenis burung. Aktivitas makan diperlukan guna mendapatkan energi untuk melakukan aktivitas-aktivitas harian seperti terbang dan berinteraksi dengan yang lainnya. Pakan yang dibutuhkan oleh burung dapat terlihat dari habitat dimana burung itu berada dan jenis paruhnya. Bertengger dengan bersuara dapat berupa nyanyian, panggilan, melakukan penyerangan atau berupa tanda adanya ancaman dari predator. Kemudian aktivitas terbang atau bergerak adalah suatu strategi dari individu atau populasi untuk menyesuaikan dan memanfaatkan keadaan lingkungannya agar dapat hidup dan berkembangbiak secara normal. Aktivitas terbang dapat terjadi setiap waktu seperti saat makan atau menjaga daerah teritori. Aktivitas burung sangat berperan penting bagi objek ekowisata burung yang menjadi daya tarik bagi wisatawan dengan nilai seni dan keindahan. Waktu mengamati burung yang baik terdapat di waktu pagi (06.00-09.00) waktu ini cukup baik untuk menjumpai burung yang melakukan aktivitasnya seperti makan, bersiul, bertengger ataupun terbang. Pada rentang waktu tersebut kita dapat 
menjumpai jenis burung yang dilindungi dan jenis burung endemik Sulawesi. Mulyadin (2013), mengatakan bahwa tingginya frekuensi makan pada rentang waktu ini disebabkan rasa lapar yang dirasakan setelah tidak makan selama waktu tidur.

Hasil penelitian menunjukkan bahwa kondisi habitat dalam keadaan yang stabil dapat dilihat dari nilai indeks keanekaragaman jenis yang tergolong rendah $\left(H^{\prime} \leq 2,30\right)$, indeks kekayaan jenis tergolong rendah $(\mathrm{Dmg}<3,5)$ serta indeks kemerataan jenis sedang serta komunitas tergolong labil $(E=0,3-0,6)$. Odum (1993), menjelaskan tingkat keanekaragaman jenis cenderung rendah dalam ekosistem yang terkendali secara fisik dan cenderung tinggi dalam ekosistem yang diatur secara biologis. Magurran (1988) menjelaskan tingkat kekayaan jenis tergolong tinggi jika nilai $\mathrm{E}$ (indeks kekayaan) di atas lima.

Indeks kesamaan jenis pada ketiga jalur pengamatan tergolong mirip. Terlihat pada indeks kesamaan yang berkisar 64\%-74\% mengindikasikan kemerataan komunitas yang mirip pada setiap jalur pengamatan $(50 \%<1 S<75 \%)$. Hal ini menunjukkan bahwa penyebaran jenis burung pada ketiga jalur pengamatan tergolong merata dan komunitas di dalam areal dalam keadaan seimbang (Magurran, 1988). Indeks keanekaragaman Shannon-Wiener yang digunakan dalam fungsi dari dua komponen yaitu kekayaan atau jumlah jenis dan indeks keseragaman antar habitat (Mendidit, 2003).

Aktivitas pengamatan burung merupakan aktivitas yang membutuhkan konsentrasi tinggi dan menitikberatkan pada proses mencari burung, mengidentifikasi dan mencatatnya. Jalur yang tidak baik akan membuat energi cepat terkuras sehingga konsentrasi pengamat burung bisa terganggu. Secara keseluruhan, jalur-jalur pengamatan yang telah ditentukan memiliki tingkat kenyamanan dan keamanan yang baik secara tipe habitat yang bervariasi memberi peluang hadirnya berbagai jenis burung sehingga sangat mendukung pengembangan ekowisata berbasis satwa liar. Burung merupakan indikator yang sangat baik untuk mengetahui kesehatan lingkungan dan nilai kekayaan keanekaragaman hayati secara keseluruhan. Hal tersebut menandakan bahwa ada suatu hubungan yang erat antara satwa dan lingkungan (Fachrul, 2008).

Berdasarkan hasil penelitian, untuk mengembangkan ketiga jalur pengamatan sebagai kawasan ekowisata berbasis bird watching, maka waktu yang paling baik bagi wisatawan untuk dapat melihat dan menikmati berbagai jenis burung pada setiap jalur pengamatan adalah di pagi hari sekitar pukul 06:00-11:00 WITA. Pada waktu tersebut kita dapat menemukan berbagai jenis burung yang sedang terbang, bertengger, dan makan. Pada jalur Tompobulu dan jalur Balleanging kita dapat menemukan beberapa jenis burung endemic sekaligus dilindungi, yaitu Julang sulawesi (Rhyticeros cassidix), Alap-alap sapi (Accipiternanus) dan Elang ular sulawesi (Spilornis rifipectus). Selain jenis burung tersebut, pada jalur Kattokaddarao kita juga dapat menemukan berbagai jenis burung yang endemic sekaligus dilindungi sulawesi pada waktu pengamatan pagi seperti, Julang sulawesi (Rhyticeros cassidix) dan Alap-alap sapi (Accipiternanus). Terdapat 2 jenis burung endemik dijumpai pada ketiga jalur pengamatan yaitu Julang sulawesi (Rhyticeros cassidix) dan Srigunting Sulawesi (Dicrurus montanus). Adapun 5 jenis burung yang hanya ditemukan pada jalur Balleanging yaitu Walet sapi (Collacolia esculenta), Burung madu sriganti (Nectariana jugularis), Bubut pacar jambul (Clamator coromandus), Kangkareng Sulawesi (Penelopides exarthatus), dan Decu belang (Saxicola caprata). Beberapa jenis burung yang muncul pada waktu tertentu seperti Julang Sulawesi (Rhyticeros cassidx) dan Kangkareng Sulawesi (Penelopidex exarthatus) yang biasanya hanya muncul diwaktu pagi dan sore hari, adapun jenis burung Kadalan Sulawesi (Phaenicophaeus calyorhynchus) yang hanya muncul apabila terdapat kelompok Monyet sulawesi (Macaca Maura). Menurut Achmad (2017), jenis-jenis endemik dan dilindungi adalah merupakan jenis yang sangat perluh untuk disampaikan kepada wisatawan.

Achmad (2017), mengatakan bahwa dalam pengembangan ekowisata alam liar, sebelumnya perlu dilakukan identifikasi kekayaan flora dan fauna pada areal perencanaan ekowisata. Untuk pengembangan ekowisata di hutan dataran rendah pada ketiga jalur pengamatan di Kompleks Gunung Bulusaraung, Taman Nasional Bantimurung Bulusaraung terlihat bahwa potensi keanekaragaman jenis burung pada setiap jalur berbeda, sehingga untuk pengelolaan kedepannya para wisatawan dapat di tawarkan dengan 3 paket ekowisata. Paket pertama yang di tawarkan pada jalur Balleanging dengan potensi keanekaragaman jenis burung paling tinggi namun dengan jalur pendakian sepanjang 2100 meter, paket kedua pada jalur Kattokaddaro dengan kondisi kelerengan tidak terlalu terjal dengan jalur pendakian sepanjang 1100 meter, dan paket ketiga dengan tingkat keanekaragaman yang cukup beragam dengan jalur sepanjang 400 meter. Aktivitas pengamatan burung yang baik dapat dilakukan pada waktu pagi dan sore hari. Untuk para wisatawan yang menginginkan jalur pendakian yang tidak terlalu tinggi/terjal dapat melakukan pengamatan burung pada hutan dataran rendah. Terutama pengamatan pada jalur Balleanging dengan tingkat kekayaan jenis burung yang cukup tinggi dengan jalur yang lebih panjang dari pada jalur Kattokaddaro dengan jalur Tompobulu.

\section{KESIMPULAN}

Berdasarkan hasil penelitian mengenai identifikasi potensi keanekaragaman jenis burung untuk pengembangan ekowisata pada hutan dataran rendah di kompleks Gunung Gulusaraung, Taman Nasional Bantimurung Bulusaraung dapat disimpulkan bahwa di hutan dataran rendah kompleks Gunung Bulusaraung, Taman Nasional Bantimurung Bulusaraung memiliki 
potensi yang tergolong rendah untuk dikembangkan menjadi ekowisata satwa liar berbasis bird watching yang terdapat di tiga jalur pengamatan, yakni jalur Balleanging, jalur Kattokaddaro dan jalur Tompobulu.Pada jalur Balleanging ditemukan 19 jenis burung (6 jenis endemik Sulawesi, 3 jenis endemik sekaligus dilindungi, dan 4 jenis dilindungi).Pada jalur Kattokaddaro ditemukan 12 jenis burung (5jenis burung endemik Sulawesi, 1 jenis endemik dan dilindungi dan 1 jenis dilindungi).Pada jalur Tompobulu ditemukan 15 jenis burung ( 8 jenis burung endemik Sulawesi, 2 jenis dilindungi dan 3 jenis endemik sekaligus dilindungi). Terdapat 7 jenis burung yang dapat dijumpai pada setiap jalur pengamatan, yaitu Layanglayang api (Hirundo rustica), Layang-layang batu (Hirundo tahitica), Walet polos (Collocalia vanikorensis), Alap-alap sapi (Falco molusccensis), Srigunting sulawesi(Dicrurus montanus), Julang sulawesi (Rhyticeros cassidix), dan Elang hitam(Ictinaetus malayensi).

\section{DAFTAR PUSTAKA}

Achmad, A. (2017). Membangun Ekowisata Alam Liar. Makassar: Universitas Hasanuddin.

Coates, B.J., \& Bishop K.D. (2000). Panduan Lapangan Burung-burung di Kawasan Wallaceae, (diterjemahkan oleh S. N. Kartika Sari, Meiske, D. Tapilahu Dan Dwiatinova Rini). Bogor: Birdlife Internasional-Indonesia Programme.

Departemen Kehutanan. (2010). Rencana Strategis Balai Taman Nasional Bantimurung Bulusaraung Tahun 2010 - 2014.

Fachrul, M.F. (2008). Metode Sampling Bioekologi. Jakarta: PT. Bumi Aksara.

Hernowo, J.B., \& Prasetyo. (1989). Konsep ruang Terbuka Hijau di KotaSebagai Pendukung Pelestarian Burung. Media Konservasi, Vol. II (4), 61-77.
Holmes, D \& Phillips K. (1999). Burung-Burung di Sulawesi. Bogor: LIPI.

Ismawan, A., Rahayu E.S., \& Dharmawan A. (2015). Kelimpahan dan Keanekaragaman Burung di Prevab Taman Nasional Kutai Kalimantan Timur. Malang: Program Studi Biologi, FMIPA, Universitas Negeri Malang.

Krebs, J.R., \& Davies N.B. (1978). Behavioural ecology: an Evolutionary Approach. London: Blackwell Scientific Publications.

MacKinnon, J. (1992). Panduan Lapangan Pengenalan Burung-burung di Jawa dan Bali. Jogyakarta: Gajah Mada University Press.

Magurran, A.E. 1988. Ecological Diversity and Its Measurement. USA: Chapman and Hall.

Mendidit, A. (2003). Komposisi Keanekaragaman Jenis Burung Di Resort Way Kanan, Taman Nasional Way Kanbas, Lampung Tengah, Lampung. KKL. Jakarta: Universitas Nasional Jakarta.

Mulyadin, R. 2013. Perilaku Harian dan Daerah Jelajah (Home Range) Burung Gosong Kaki-Merah (Megapodius reinwardt Dumont) di Loh Buaya, Taman Nasional Komodo. [Skripsi]. Makassar: Fakultas Kehutanan Universitas Hasanuddin.

Odum, E.P. (1993). Dasar-dasar Ekologi.Edisi kedua. (terjemahan). Yogyakarta: Universitas Gajah Mada.

Partapasmita, R. (2003). Burung Pemakan Buah dan Peranannya Sebagai Penyebar Biji. Makalah Falsafah Sains Program Pasca Sarjana. Bogor: Insititut Pertanian Bogor.

Sukmantoro, W., Irham M., Novarino W., Hasudungan F., \& Muchtar K. N. (2007). Daftar Burung Indonesia No. 2. Bogor: Indonesian Ornithologist's Union.

Tortosa, F.S., \& Villafuerte R. (2000). Habitas Selecttion by Flocking Winkring Common Cranes (Grur grus) at Los Pedrochos Valley, Span. Etologia. 8:21-24.

Welty, J.C. (1982).The Life of Bird. Philadelphia, USA: Saunders Collage Publising.

Yoeti, O.A. (2000). Ekowisata: Pariwisata Berwawasan Lingkungan Hidup. Jakarta: P.T. Pertja. 